\title{
AGRO EDU WISATA DESA SWARU KECAMATAN PAGELARAN KABUPATEN MALANG PROPINSI JAWA TIMUR
}

\author{
Sudiyono ${ }^{1}$, Maris Kurniawati ${ }^{2}$, Rita Indah Mustikowati ${ }^{3}$ \\ ${ }^{1}$ Prodi PGSD Fakultas IImu Pendidikan Universitas Kanjuruhan Malang \\ ${ }^{2}$ Prodi Fisika Fakultas Sains dan Teknologi Universitas Kanjuruhan Malang \\ ${ }^{3}$ Prodi Manajemen Fakultas Ekonomika dan Bisinis Universitas Kanjuruhan Malang \\ E-mail : sudiyono@unikama.ac.id
}

\begin{abstract}
Abstrak
Pertemuan dan diskusi dengan perangkat desa serta para tokoh masyarakat menyepakati untuk berusaha mengembangkan Desa Suwaru yang juga dikenal sebagai "Kampung Salak" tersebut untuk menjadi desa wisata dengan kekhasannya pada wisata Agro, outbound, serta kesenian. Pengembangan Suwaru menjadi desa wisata sejalan dengan program utama Pemerintah Kabupaten Malang yang salah satu program besarnya adalah pengembangan bidang pariwisata. Saat ini Wisata Petik Salak di desa Suwaru dijadikan salah satu bagian dari pengembangan wisata Kabupaten Malang. Metode yang ditawarkan melalui PPDM untuk mengembangkan "Agro-eduwisata desa Suwaru" tersebut adalah (1) Pemantapan dan penguatan pengembangan desa agro-eduwisata, (2) Alih teknologi dalam pengelolaan wisata desa, (3) Pelatihan dan pendampingan dalam manajemen pariwisata desa, (4) Studi banding pengelolaan desa wisata, (5) Pengembangan dan pengisian spot-spot wahana wisata, (6) Pelatihan, pendampingan, dan penyiapan SDM pengelola wisata, (7) Pelatihan dan pendampingan dalam manajemen pemasaran wisata.
\end{abstract}

Kata Kunci : potensi desa, agro-eduwisata, manajemen wisata desa, sumberdaya manusia

\section{PENDAHULUAN}

Indonesia merupakan Negara yang dianugerahi kekayaan alam yang berlimpah-limpah. Jika dilihat dari sumber daya alamnya, negara meningkatkan memiliki peluang untuk kesejahteraan penduduknya. Akan tetapi kenyataannya, sebagian besar penduduknya masih hidup dibawah kesejahteraan. Melihat fenomena tersebut maka kita tidak bisa melihat hanya dari satu sisi permasalahan, namun banyak faktor yang menimbulkan kondisi tersebut terjadi. Kemajuan suatu negara tidak hanya ditentukan oleh ketersediaan sumber daya alam atau modal, namun ditentukan oleh bagaimana masyarakat desa dapat memberdayakan potensi desa untuk dapat difungsikan secara optimal bagi kesejahteraan masyarakat.

Kecamatan Pagelaran Desa Swaru memiliki potensi yang beragam seperti Potensi desa yang sangat besar sebagai penghasil salak dan letak lokasi yang dijalur daerah wisata pantai selatan kabupaten malang, wilayah geografis desa yang alami serta lingkungan masyarakat yang homogen yang menjadi daya tarik wisata alam, wisata budaya dan wisata minat seperti agro wisata. Agro wisata merupakan merupakan sebuah alternatif untuk meningkatkan pendapatan atau menggali potensi ekonomi masyarakat desa. Selain itu agrowisata saat ini dikembangkan sebagai bentuk pelestarian lingkungan.

Pengembangan agrowisata atau desa wisata akan membangun komunikasi yang intensif antara petani, masyarakat desa dengan wisatawan. Selain itu diharapkan dengan agrowisata tercipta sinergi antara pemerintah daerah dan masyarakat dalam mendorong percepatan pembangunan daerah pedesaan. Agrowisata berguna dalam upaya untuk pembangunan dan pengembangan ekonomi warga. Secara umum lingkup dan potensi agrowisata dapat dikembangkan seperti perkebunan, tanaman pangan dan hortikultural, perikanan, peternakan serta kehutanan.

Berdasarkan hasil diskusi dengan Mitra ditemukan permasalahan yang mendasar 
dihadapi mitra, yaitu belum dimilikinya kesadaran warga masyarakat terhadap potensi yang dimiliki oleh desanya, sehingga potensi tersebut cenderung diabaikan dan disia-siakan bahkan ada kecenderungan untuk dihilangkan. Secara rinci dapat disebut beberapa permasalahannya adalah : (1) tanaman salak telah digantikan dengan jenis tanaman pertanian yang lain antara lain tebu, pepaya, kayu sengon yang dianggap memiliki nilai jual lebih tinggi; (2) terjadi pendangkalan embung desa yang dipenuhi lumpur dan enceng gondok sehingga debit air berkurang dan tidak bisa maksimal, dari kedalaman lebih dari 10 meter sekarang tinggal kurang dari 5 meter; (3) lokasi pemancingan yang belum tertata dan belum dikelola dengan maksimal; (4) tanah bertebing yang belum difungsikan secara optimal; (5) minimnya warga masyarakat yang mengembangkan dan mengolah potensi salaknya (6) jalur wisata menuju pantai selatan belum difungsikan untuk menarik wisatawan domestic; (7) belum banyak masyarakat yang mengetahui bahwa di desa Suwaru memiliki gereja yang berumur ratusan tahun,

Melalui dialog dan diskusi dengan ketiga mitra tersebut permasalahan yang mendesak untuk diselesaikan pada tahap pertama ini adalah : (1) meningkatkan wawasan warga dalam mengenali potensi yang dimiliki oleh dirinya dan lingkungannya (2) memantabkan niat dan kemauan serta semangat warga masyarakat setempat dalam mewujudkan Desa Suwaru sebagai desa wisata, (3) menata kawasan desa dengan menentukan spot-spot wahana wisata desa; (4) mengisi beberapa wahana outbond sebagai bagian dari kegiatan wisata, antara lain menata lingkungan pemancingan, kawasan perkemahan, area rumah pohon dan sebagainya (5) mempersiapkan dan melatih sumberdaya manusia terutama karang taruna untuk menjadi pengelola wisata desa, (6) melakukan studi banding ke beberapa desa yang sudah berhasil menjadi desa wisata seperti di wilayah Gunung Kidul Yogyakarta, Kampung Kid di kota Batu dan lain-lain; (7) membantu memberdayakan kegiatan kesenian yang ada untuk dapat difungsikan sebagai salah satu kegiatan wisata; (8) mendorong pemerintah daerah dalam membangun pedesaan dengan merevitalisasi keberadaan embung desa sebagai sumber air yang sangat vital bagi irigasi pertanian yang sekaligus dapat difungsikan sebagai arena wisata air.

Peluang dari kegiatan agrowisata terletak dari dukungan masyarakat lokal dan pemerintah. Jika pihak pengelola belum melakukan riset pasar dan target pasar belum jelas akan menimbulkan ancaman persaingan dengan objek wisata sejenis. Sehingga pengelola perlu memiliki strategi berdasarkan analisa SWOT anatara lain dibangunnya fasilitas-fasilitas, meningkatkan loyalitas pengunjung, menciptakan sistem manjerial keuangan, menciptakan kegiatan promosi dan pemasaran, menjalin hubungan dengan obyek wisata lain dan travel agent, meningkatkan mutu kualitas dan ciri khas daerah, dan menerapkan pelatihan dan pengembangan SDM. Pengembangan agrowisata pada konsep universal dapat ditempuh melalui diversifikasi.

\section{METODOLOGI}

Metode yang dikembangkan adalah pemantapan, penguatan dan pengembangan desa agro-eduwisata, alih teknologi dan pengelolaan wisata desa, pelatihan dan pendampingan dalam manajemen pariwisata desa, studi banding pengelolaan desa wisata, pengembangan dan pengisian spot-spot wahana wisata, pelatihan, pendampingan dan penyiapan SDM pengelola desa wisata, pelatihan dan pendampingan dalam manajemen pemasaran desa wisata.

Pengabdian kepada masyarakat ini dilakukan dengan proses menjaring kebutuhan antara lain kebutuhan mitra, peran mitra, sinkronisasi jadwal kegiatan, mengembangkan solusi yang ditawarkan, mengembangkan materi sosialisasi selanjutnya pelatihan dan pendampingan kepada kelompok mitra binaan. Kehadiran pengabdi di lokasi masyarakat dilakukan bertahap, mulai dari perkenalan, menyampaikan tujuan dan perijinan sampai seluruh data yang diperlukan terkumpul. Pengabdi juga berperan sebagai instrumen pengumpul data dalam focus group discussion pengembangan usaha agro eduwisata di Desa Swaru Kecamatan 
Pagelaran, Kabupaten Malang; dan review sejawat terhadap hasil pengabdian.

\section{HASIL DAN PEMBAHASAN}

Kegiatan mengembangkan potensi desa menjadi agro eduwisata memiliki nilai ekonomis tinggi dengan menggunakan konsep pemberdayaan masyarakat berbasis ekonomi kerakyatan di Desa Swaru Kecamatan Pagelaran Kabupaten Malang. Dalam rangka memantapkan program kegiatan pengabdian masyarakat untuk mewujudkan Desa Suwaru sebagai Desa Agro-Eduwisata, maka semua pihak perlu dilibatkan agar warga masyarakat benarbenar merasa terlibat dan ikut memiliki. Oleh karena itu dilakukan koordinasi dengan perangkat desa, perwakilan mitra dan perwakilan masyarakat. Pada kordinasi tersebut dibahas mengenai berbagai peluang pengembangan desa dan pemberdayaan ekonomi warga. Secara umum masyarakat setempat dan perangkat desa sangat antusias menyambut program ini. Pada kesempatan kordinasi tersebut sekaligus menjadi ajang komunikasi yang sangat intensif antara para anggota masyarakat,mitra dan perangkat desa. Peranan masing-masing komponen masyarakat dalam pengembangan desa akhirnya juga dibahas bersama, seperti bagaimana mendorong para karangtaruna serta kegiatan untuk anak dan remaja, khususnya dalam bidang kesenian.

Guna memperoleh masukan dan bahan pembelajaran untuk persiapan pengembangan desa wisata, maka team beserta mitra melakukan studi banding ke kawasan wisata edu wisata yang dikenal sebagai kampung kids. Di tempat wisata tersebut, team mendapat penjelasan dan pendampingan dari perwakilan kampung kids. Kampung kids merupakan area wisata yang dipadukan dengan aktifitas pendidikan, pembelajaran, pelatihan, dan pembentukan karakter. Pelaksana pengelolaan di kampung kids dilakukan oleh para siswa sendiri beserta seniornya yang memang masih terpanggil untuk melanjutkan karier disana. Berbagai wahana mainan outbond, maupun area pertanian, peternakan, industri kecil, pendidikan, pertokoan, kuliner, olahraga, pementasan, serta tempat-tempat pelatihan seperti aula ataupun ruang meeting tersedia lengkap. Model yang wisata yang ada di kampung kids tersebut sebagian dapat dikembangkan juga di desa suwaru nantinya. Misalnya untuk area peternakan, dimungkinkan para pengunjung di suarau anntinya dapat diarahkan menyaksikan langsung cara beternak yang dilakukan oleh masyarakat setempat. Untuk itu nantinya peternakan milik warga suwaru yang ditunjuk dapat dibantu melakukan perbaikan ataupun pembenahan di kandang masing-masing.

Selama berada di lokasi wisata tersebut, team pengabdi dan mitra benarbenar mendapatkan bekal pengetahuan yang sangat berharga. Di samping itu hal yang sangat menggembirakan adalah motivasi mitra yang meningkat setelah pulang dari studi banding tersebut. Masingmasing memiliki perasaan dan harapan yang tinggi akan keberhasilan pengembangan desa suwaru sebagai desa wisata. Melalui kegiatan pengabdian masyarakat ini juga diberikan dukungan terhadap pengembangan kegiatan kesenian untuk anak-anak dan remaja Desa Suwaru. Dukungan terhadap pengembangan kesenian ini disambut gembira oleh warga masyarakat maupun gereja. Antara lain untuk tempat berlatih anak-anak, Gereja menyediakan fasilitas dan tempat latihan tari. Kemudian warga masyarakat melalui anak-anak yang ikut berkesenian secara suka rela bersedia berkontribusi untuk membayar iuran untuk menunjang perkembangan kesenian Desa Suwaru. Perkembangan kesenian anakanak saat ini cukup baik. Mereka sering diundang untuk mengisi acara di Gereja baik di desa sendiri maupun desa lain. Guna mendukung pengadaan pengembangan lokasi perkemahan dan outbond di mitra 1 maka tim pengabdi memberikan bantuan berupa wahana mainan anak-anak. Pada tahap ini mitra 1 diberkan bantuan pengadaan empat unit wahana mainan anak-anak. Di lokasi mitra 1 tersedia kebun salak dengan luas sekitar 1 hektar sebagai lokasi wisata petik salak. Saat ini salak di kebun tersebut masih berumur sekitar 1 bulan dan biasanya pada bulan Desember hingga Januari buah salak tersebut sudah siap panen. Lokasi 
kebun salak yang bersebelahan dengan area yang direncanakan sebagai tempat perkemahan tentu menjadi daya tarik tersendiri. Di samping itu, tidak jauh dari lokasi ini juga terdapat tanaman buahbuahan yang lain seperti rambutan, durian, langsep, manggis, dan jeruk. Pada saat musim berbuah lingkungan ini benar-benar menarik.

Di tengah Desa Suwaru terdapat aliran air sungai yang mengalir sepanjang tahun karena mata airnya berasal dari embung milik desa.Untuk memberdayakan aliran air tersebut maka tim pengabdi mengajak masyarakt setempat untuk memelihara ikan di karamba. Dengan inisiasi oleh tim pengabdi maka pengadaan karamba beserta ikannya diberikan bantuan sebanyak 3 karamba yang kemudian dilanjutkan oleh warga desa untuk memambah jumlah karamba sehingga sekarang sudah ada 15 karamba ikan.

\section{KESIMPULAN}

Desa Suwaru memiliki potensi yang besar untuk dikembangkan menjadi desa wisata, karena adanya spot-spot yang bisa dikembangkan sebagai area destinasi wisata. Beberapa spot wisata saat ini telah mulai dirintis pengembangannya oleh beberapa warga masyarakat, baik terkait asesabilitas, amenities, dan apertise. Untuk membantu mewujudkan keinginan masyarakat desa Suwaru tersebut, kehadiran team pengabdian masyarakat Universitas Kanjuruhan Malang yang didukung oleh Kemenristek Dikti benarbenar memperoleh sambutan yang positip dari masyarakat. Inisiasi dari team pengabdi yang dikomunikasikan dengan mitra menghasilkan kegiatan yang sangat bermanfaat. Diharapakan kelanjutan dari program ini akan berdampak positif bagi pengembangan dan pemberdayaan ekonomi warga.

\section{DAFTAR PUSTAKA}

Alma, B. 2000. Kewirausahaan. Bandung: Penerbit Alfabeta.
Nusastiawan, C.D. 2017. Buku Pedoman Umum Desa Wisata. http://www.academia.edu/6423956/ diunduh 01 Juni 2017.

Sastrayuda, G.S. 2010. Hand Out Mata Kuliah Concept Resort And Leisure, Strategi Pengembangan dan Pengelolaan Resort dan Leisure. http://r.search.yahoo.com/ ylt=A2oK mMv1kF1ZPDMAMDr3RQx. Diunduh 01 Juni 2017.

Sudana, P.I.2013. Strategi Pengembangan Desa Wisata Ekologisd dii Desa Belimbing, Kecamatan Pupuan Kabupaten Tabanan. Analisis Pariwisata. Volume 13 No 1. Hal.1131. ISSN: 1410-3729.

Suryana, 2003. Kewirausahaan: Pedoman Praktis, Kiat dan Proses Menuju Sukses. Edisi Revisi, Jakarta: Penerbit Salemba Empat.

Suryana, Y \& Bayu, K. 2011. Kewirausahaan: Pendekatan Karakteristik Wirausahawan Sukses. Penerbit Kencana, Prenada Media Group. Jakarta.

Wijatno, S. 2009. Pengantar Entrepreneurship. PT Gramedia Widiarsarana. Jakarta: 